\title{
Animal welfare in experimental orthopedic surgery of dogs: an analysis of the Brazilian view
}

\section{Rosângela Rumi Sugauara ${ }^{1}$ Elisângela Yumi Sugauara ${ }^{1}$ Luciana Kazue Otutumi $^{2}$ Ricardo de Melo Germano ${ }^{2}$ () Elaine Yae Yamashita Sugauara ${ }^{1}$ Ana Maria Quessada ${ }^{2 *}$}

${ }^{1}$ Programa de Pós-graduação em Biotecnologia Aplicada a Agricultura, Universidade Paranaense (UNIPAR), Umuarama, PR, Brasil. ${ }^{2}$ Programa de Pós-graduação em Ciência Animal com Ênfase em Produtos Bioativos, Universidade Paranaense (UNIPAR), Praça Mascarenhas de Moraes, 4282, Centro, Umuarama, 87502-100, PR, Brasil. E-mail: quessadavet@gmail.com. "Corresponding author.

\begin{abstract}
The aim of this paper was to conduct a bibliometry search about Brazilian scientific publications that describe experimental orthopedic surgeries in dogs. It was analyzed 14 publications, and there was wide variation in the number of experimental animals, showing that there is no consensus on the appropriate number for science experiment with dogs. Most articles had been reviewed by an ethics committee $(13 / 14,92.85 \%)$ and only two articles $(2 / 14 ; 14.28 \%)$ did not report the use of analgesic protocol. Among analgesics, morphine was the most widely used, noted in seven studies (7/14; 42.85\%). In six of the articles (6/14; 42.85\%), the final destination of animals was not informed, but in four experiments $(4 / 14 ; 28.57 \%)$ the dogs were euthanized. In four studies $(4 / 14 ; 28.57 \%)$ the animals were sent for adoption. In conclusion, the ethics in animal research in Brazil has advanced, but is necessary proper planning in sample size.
\end{abstract}

Key words: analgesia; animal experimentation; ethics committee; surgical orthopedic.

Bem-estar animal em cirurgia ortopédica experimental de cães: uma análise da visão brasileira

RESUMO: $O$ objetivo do presente artigo foi realizar uma pesquisa bibliométrica sobre publicações cientificas brasileiras que descrevem cirurgias ortopédicas experimentais em cães. Foram analisadas 14 publicações, havendo grande variação no número de animais experimentais, demonstrando que não há consenso sobre o número adequado para um experimento científico ortopédico com cães. A maioria tinha sido analisada por um comitê de ética (13/14; 92,85\%) e apenas dois artigos (2/14; 14,28\%) não informaram o uso de protocolo analgésico. Entre os analgésicos, a morfina foi a mais utilizada, tendo sido observada em sete estudos (7/14; 42,85\%). Em seis publicações (6/14; 42,85\%) o destino final dos animais não foi informado, mas em quatro experimentos $(4 / 14 ; 28,57 \%)$ os cães foram eutanasiados. Também em quatro estudos (4/14; 28,57\%) os animais foram encaminhados para adoção. Em conclusão, a ética em pesquisa animal no Brasil avançou, mas há necessidade de planejamento adequado no número amostral.

Palavras-chave: analgesia; cirurgia ortopédica; comitê de ética; experimentação animal.

Since 2008, Brazil passed Law No. 11.794 (Arouca Law) that deals about the scientific use of animals. The text of the Law mentions that is essential for the accreditation of institutions with teaching or research activities with animals, the formation of the Ethics Committee on Animal Use (ECAU) (BRASIL, 2008).

Starting from Law, researchers who requested the use of experimental animals, must submit their experiments to the ethics committee. At the same time, periodics now requires the protocol of the committees.

The aim of this article was to conduct a bibliometry search with analysis of Brazilian scientific publications that describe experimental orthopedic surgeries in dogs, published between 2008 and 2016, from the point of view of animal welfare.

It was made a search bibliometric in the site Google scholar using the following expressions: ethics animal committee, experimental surgery in dogs, orthopedic surgery in dogs Brazil. Only publications produced by Brazilian researchers were collected. Articles that were submitted for publication before 2008 (year in which Arouca law was promulgated) and articles that used routine animals (non-experimental) were excluded. With these criteria were rescued 14 publications. After analysis, results were displayed in tables with descriptive analysis.

Currently, one of the basic principles of animal experimentation with ethical and 
humanitarian way provides for the use of the smallest possible number of animals (DAMY et al., 2010). However, in the 14 analysed articles was observed that there was great variation in the number of experimental animals (Table 1), showing that there is no consensus on the appropriate number for a scientific experiment on dogs, which can lead to a deficiency in the experimental design.
The correct calculation for the sample size, is a fundamental point to success in scientific research. This calculation must be performed by appropriate statistical tests to determine the sample size. (MAROTTI et al., 2008; FONTELES et al., 2010). However, by analysing the articles presented here, such calculation was not carried out, resulting in such disparate figures.

Table 1 - Analysis of Brazilian publications that describes experimental orthopedic surgeries in dogs from the point of view of animal welfare $(\mathrm{n}=14)$ from 2008 to 2016.

\begin{tabular}{|c|c|c|c|c|c|c|c|}
\hline \multirow{2}{*}{ Author and year } & \multirow{2}{*}{$\begin{array}{c}\text { Number of } \\
\text { the } \\
\text { animals }\end{array}$} & \multirow{2}{*}{$\begin{array}{l}\text { Approval } \\
\text { by Ethical } \\
\text { Committee }\end{array}$} & \multirow{2}{*}{ Statistic } & \multirow{2}{*}{$\begin{array}{l}\text { Analgesic } \\
\text { Protocol }\end{array}$} & \multicolumn{2}{|c|}{----------------Used analgesic--------------- } & \multirow{2}{*}{$\begin{array}{l}\text { Destination of } \\
\text { animals }\end{array}$} \\
\hline & & & & & Preoperative & Postoperative & \\
\hline $\begin{array}{l}\text { MINTO et al., } \\
2008\end{array}$ & 10 & $\mathrm{Y}$ & $\mathrm{N}$ & NI & NI & NI & Donation \\
\hline $\begin{array}{l}\text { RICHTER et al., } \\
2009\end{array}$ & 14 & Y & $\mathrm{Y}$ & $\mathrm{Y}$ & Morphine & $\begin{array}{l}\text { Flunixin- } \\
\text { meglumine }+ \\
\text { morphine }\end{array}$ & NI \\
\hline $\begin{array}{l}\text { SIA et al., } \\
2009\end{array}$ & 16 & NI & $\mathrm{Y}$ & $\mathrm{Y}$ & Pethidine & NI & $\begin{array}{c}\text { Euthanasia } \\
\text { (Thiopental + } \\
\text { magnesium } \\
\text { sulfate) }\end{array}$ \\
\hline $\begin{array}{l}\text { COELHO et al., } \\
2010\end{array}$ & 6 & Y & Y & $\mathrm{Y}$ & NI & Ketoprofen & $\begin{array}{c}\text { Euthanasia } \\
\text { (anesthetic } \\
\text { overdose) }\end{array}$ \\
\hline $\begin{array}{l}\text { COSTA NETO et } \\
\text { al., } 2010\end{array}$ & 10 & Y & $\mathrm{Y}$ & Y & $\begin{array}{c}\text { Ketoprofen }+ \\
\text { pethidine }\end{array}$ & $\begin{array}{l}\text { Tramadol + } \\
\text { ketoprofen }\end{array}$ & NI \\
\hline $\begin{array}{l}\text { MÜLLER et al., } \\
2010\end{array}$ & 20 & $\mathrm{Y}$ & $\mathrm{Y}$ & $\mathrm{Y}$ & $\begin{array}{c}\text { Fentanyl + lidocaine } \\
\text { and bupivacaine } \\
\text { epidural }\end{array}$ & $\begin{array}{l}\text { Parecoxib }+ \\
\text { tramadol }\end{array}$ & NI \\
\hline $\begin{array}{l}\text { OLIVEIRA et al., } \\
2010\end{array}$ & 18 & $\mathrm{Y}$ & $\mathrm{Y}$ & $\mathrm{Y}$ & Fentanyl + morphine & Meloxicam & Adoption \\
\hline $\begin{array}{l}\text { SOUZA et al., } \\
2011\end{array}$ & 11 & $\mathrm{Y}$ & Y & Y & Morphine & $\begin{array}{c}\text { Morphine }+ \\
\text { Tramadol }+ \\
\text { brachial plexus } \\
\text { block with } \\
\text { lidocaine }\end{array}$ & Adoption \\
\hline $\begin{array}{l}\text { IAMAGUTI et al., } \\
2012\end{array}$ & 10 & Y & $\mathrm{Y}$ & $\mathrm{Y}$ & NI & $\begin{array}{l}\text { Morphine }+ \\
\text { meloxicam }\end{array}$ & NI \\
\hline $\begin{array}{l}\text { IAMAGUTI et al., } \\
2013\end{array}$ & 10 & Y & $\mathrm{Y}$ & NI & NI & NI & NI \\
\hline $\begin{array}{l}\text { MULLER et al., } \\
2013\end{array}$ & 20 & Y & $\mathrm{Y}$ & $\mathrm{Y}$ & Morphine & NI & Adoption \\
\hline $\begin{array}{l}\text { MESSORA et al., } \\
2013\end{array}$ & 10 & Y & Y & Y & Morphine & Tramadol & $\begin{array}{c}\text { Euthanasia } \\
\text { (thiopental } \\
\text { overdose) }\end{array}$ \\
\hline $\begin{array}{l}\text { SILVA \& } \\
\text { MANISCALCO, } \\
2013\end{array}$ & 7 & $\mathrm{Y}$ & $\mathrm{N}$ & $\mathrm{Y}$ & Pethidine & Tramadol & NI \\
\hline $\begin{array}{l}\text { VALENTE et al., } \\
2016\end{array}$ & 15 & $\mathrm{Y}$ & Y & Y & $\begin{array}{c}\text { Morphine + epidural } \\
\text { lidocaine }\end{array}$ & Tramadol & $\begin{array}{c}\text { Euthanasia } \\
\text { (thiopental } \\
\text { overdose }+ \\
\text { potassium } \\
\text { chloride) }\end{array}$ \\
\hline
\end{tabular}


In two studies were not conducted statistical tests $(2 / 14,14.28 \%)$ (Table 1$)$. Using statistical tests the researcher can present more reliable results even with small numbers of animals, featuring a research within the ethical principles recommended by Brazilian Law (BRASIL, 2008). Standardized procedures, accurate methods to measure answers and well-defined objectives allow accept or reject the initial hypothesis, even with the reduced number of animals (PUOPOLO, 2004).

Only two articles $(2 / 14,14.28 \%)$ did not report the use of the analgesics (Table 1). Results of such experiments can be questioned, since it does not alleviate pain, is harmful, physiological functions stays compromised, animals reduce daily food and water intake causing cardiovascular and respiratory disorders, immunosuppression and delayed healing process (SAMPAIO, 2010). In addition, absence of analgesic protocol is impediment to approval of the experiment by ECAU (BRASIL, 2008).

In $10(10 / 14,71.42 \%)$ of the 14 articles (Table 1), it was detected the use of analgesics preoperatively (preemptive analgesia). In the case of orthopedic surgical procedures, focus of the study here presented, preemptive analgesia is important for pain control postoperatively (YAMAZAKI et al., 2011).

In two experiments $(2 / 14 ; 14.28 \%)$ did not report the use of analgesics at any time (Table 1). This conduit is not in accordance with animal welfare, since orthopedic procedures induces more intense pain than other surgical procedures, because the bone injury is more painful than soft tissue injury (EKMAN \& KOMAN, 2005).

In seven studies $(7 / 14 ; 50 \%)$, there was the use of more than one drug in the analgesic protocol (Table 1), characterizing analgesic protocol called multimodal therapy that aims the association of analgesic drugs with different mechanisms of action or the application of two or more treatment modalities to provide good pain control with minimal adverse effects (LAMONT, 2008).

Among the analgesic, morphine was used most frequently, and has been noted in seven studies $(7 / 14 ; 42.85 \%)$ (Table 1). Morphine is an effective analgesic widely used in Veterinary Medicine (QUANDT et al., 2005) because controls acute pain with efficacy and safety (LAMONT, 2008).

Tramadol was used in six articles $(6 / 14$, $42.85 \%$ ), but only in the postoperative period. The use of tramadol postoperatively as single agent is not sufficient to control postoperative pain in dogs undergoing orthopedic surgery, since these surgeries produces severe pain (YAMAZAKI et al., 2011). To be more effective in controlling postoperative pain in this type of surgery, tramadol should be used preoperatively (YAZBEK \& FANTONI, 2005).

In two articles $(2 / 14 ; 14.28 \%)$ were used only non-steroidal anti-inflammatory drugs (NSAID), in the control of postoperative pain (Table 1). The NSAIDs used singly are not effective to control pain in orthopedic surgeries in dogs, unless they are employed preoperatively (YAMAZAKI et al, 2011), which did not occur in those studies (COELHO et al., 2010; OLIVEIRA et al., 2010).

About destination of animals, the Arouca Law provides that animals used in research must to be euthanized, according to methods approved by Brazilian Law (BRASIL, 2008). However, of the 14 publications analysed in six of them $(6 / 14$, $42.85 \%$ ), the final destination of the animals was not reported (Table 1). Euthanasia was the destination of animals in four experiments (4/14, $28.57 \%$ ) (Table 1), and the methods employed are in agreement with the recommendations of the Brazilian Law (BRASIL, 2013).

In four studies $(4 / 14,28.57 \%)$ animals were sent for adoption or donation (Table 1). The Brazilian Law states that, exceptionally, the animals used in experiments or demonstrations which are not subjected to euthanasia may leave the vivarium after the intervention, heard their Ethics Committee, on the criteria of security. Moreover, the animals must be sent to suitable persons or animal protection organization duly legalized, that wants to be responsible for these animals (BRASIL, 2008).

The advancement of ethics in animal research in Brazil was evident since the enactment of the Arouca Law. For comparison, in experimental orthopedic surgery published in 1999 (therefore, before the law was enacted) 30 dogs were used, and all were euthanized (GALVÃO et al., 1999). In the analysed articles the largest sample numbers were 20 dogs (MÜLLER et al., 2010; MULLER et al., 2013). However, there was much disagreement in the sample size, showing lack of consensus among Brazilian researchers, which can hinder the rational use of animals in scientific experiments.

Although, in most studies analgesics have been administered, such conduct was not unanimous, which may even compromise research results. 


\section{ACKNOWLEDGEMENTS}

To the Universidade Paranaense (UNIPAR)

\section{DECLARATION OF CONFLICTING INTERESTS}

The authors declared no potential conflicts of interest with respect to the research, authorship, and/or publication of this article.

\section{REFERENCES}

BRASIL, 2008. Lei $\mathrm{n}^{\circ} 11.794$, de 8 de outubro de 2008. Diário Oficial da República Federativa do Brasil, Poder Executivo, Brasília, DF, 9 out. 2008. Seção 1, p. 1. Available from: <http:// www.planalto.gov.br/ccivil_03/_ato2007-2010/2008/lei/111794. htm>. Accessed: Dec. 12, 2017.

BRASIL. Ministério da Ciência, Tecnologia e Inovação. Conselho Nacional de Controle De Experimentação Animal - CONCEA. Diretrizes da prática de eutanásia do CONCEA. Brasília, 2013. 54p. Available from: <http://www.clp.unesp.br/Home/ AreaTecnicaAcademica/diretrizes-concea-2013.pdf $>$. Accessed: Dec. 12, 2016.

COELHO, P.G. et al. Early bone healing around different implant bulk designs and surgical techniques: a study in dogs. Clinical Implant Dentistry and Related Research, v. 12, n.3, p. 202208, 2010. Available from: <https://onlinelibrary.wiley.com/doi/ full/10.1111/j.1708-8208.2009.00153.x >. Accessed: Nov. 10, 2016. doi: $10.1111 / \mathrm{j} .1708-8208.2009 .00153 . \mathrm{x}$

COSTA NETO, J.M. et al. Seaweed flour ("Lithothamnium calcareum") as a mineral supplement in the bone healing of a cortical autograft in dogs. Revista Brasileira de Saúde e Produção Animal, v. 11, n. 1, p. 217-230, 2010. Available from: $<$ https://www.repositorio.ufba.br/ri/bitstream/ri/1981/1/13427495-1-PB.pdf>. Accessed: Nov. 10, 2016.

DAMY, S.B. et al. Fundamental aspects in animal research as applied to experimental surgery Revista da Associação Médica Brasileira, v.5 6, n. 1, p. 103-11, 2010. Available from: <http://www.producao. usp.br/bitstream/handle/BDPI/8744/art DAMY Aspectos fundamentais_da_experimentacao_animal_aplicacoes_2010. pdf? sequence=1\&isAllowed=y $>$. Accessed: Jul. 22, 2017.

EKMAN, E.F.; KOMAN, L.A. Acute pain following musculoskeletal injuries and orthopaedic surgery. Mechanisms and management. Instructional course lectures, v. 54, p. 21-33, 2005. PMID: 15948432

FONTELES, M.J. et al. Scientific research methodology: guidelines for size sample calculation. Revista Paraense de Medicina, v.24, n.2, p.57-64, 2010. Available from: $<$ http://files. bvs.br/upload/S/0101-5907/2010/v24n2/a2125.pdf>. Accessed: Mar. 27, 2018.

GALVÃO, S.R. et al. Histologic study of conjunctive tissue $\mathrm{s}$ reaction around bone plates made from polyvinyl chloride \{PVC) in dogs. Revista Brasileira de Ciência Veterinária, v. 6, n. 3, p. 127-132, 1999. Available from: <file://C:/Users/quess/ Downloads/1136-4288-1-SM.pdf>. Accessed: Jul. 22, 2017. doi: 10.22409 /rbcv.v6i3.1136.
IAMAGUTI, L.S. et al. The repair of osteochondral defects in dogs with homologous articular chondrocytes and biosynthetic celulose membrane: clinical, ultrasound and macroscopic evaluation. Arquivo Brasileiro de Medicina Veterinária e Zootecnia, v. 64, n. 6, p. 1483-1490, 2012. Available from: <https://repositorio.unesp. br/bitstream/handle/11449/17045/S0102-09352012000600012. pdf? sequence $=1 \&$ isAllowed $=\mathrm{y}>$. Accessed: Sept. 25, 2016 .

IAMAGUTI, L.S. et al. Homologous articular chondrocytes implantation in osteochondral defects of dogs: technique and histopathological evaluation standardization. Arquivo Brasileiro de Medicina Veterinária e. Zootecnia, v. 65, n. 1, p. 82-90, 2013. Available from: $<$ http://www.scielo.br/scielo.php?script $=$ sci artte xt\&pid=S0102-09352013000100013 >. Accessed: Aug. 18, 2017. doi: 10.1590/S0102-09352013000100013.

LAMONT, L. A. Multimodal Pain management in veterinary medicine: the physiologic basis of Pharmacologic therapies. Veterinary Clinics of North America Small Animal Practice, v. 38 , n. 10 , p. 1173-1186, 2008. Available from: <https://www. sciencedirect.com/science/article/pii/S0195561608001319>. Accessed: Jul. 11, 2013. doi: 10.1016/j.cvsm.2008.06.005.

MAROTTI, J. et al Sampling in clinical research: sample's size. Revista de Odontologia da Universidade Cidade de São Paulo, v. 20, n.2, p. 186194, 2008. Available from: <http://arquivos.cruzeirodosuleducacional. edu.br/principal/old/revista_odontologia/pdf/maio_agosto_2008/ Unicid 20(2 12) 2008.pdf $>$. Accessed: Mar. 27, 2018.

MESSORA, M. R. etal.Effect of platelet-rich plasma on bonehealing of fresh frozen bone allograft in mandibular defects: a histomorphometric study in dogs. Clinical oral implants research. v. 24, n. 12, p. 1347-1353, 2013. Available from: <https://onlinelibrary.wiley.com/ doi/epdf/10.1111/clr.12008?purchase_site_license=LICENSE_ DENIED\&show checkout $=1 \& \mathrm{r} 3$ referer $=$ wol\&purchase referrer $=$ onlinelibrary.wiley.com\&tracking_action=preview_click $>$. Accessed: Sept. 25, 2016. doi: 10.1111/clr.12008.

MINTO, B. W. et al. Total hip arthroplasty in dogs. Experimental study using a prosthesis made in Brazil. Ciência Rural, v. 38, n. 1, p. 136-142, 2008. Available from: <http://www.redalyc.org/ pdf/331/33138122.pdf > . Accessed: Feb. 02, 2017.

MÜLLER, D. C. M. et al. Synthetic implant as a stabilizer link, after desmotomy of the cruciate ligaments in dogs - Proposition technique. Ciência Rural, v. 40, n. 6, p. 1327-1334, 2010. Available from: <http:// www.redalyc.org/articulo.oa?id=33117724008>. Accessed: Feb. 08, 2017.

OLIVEIRA, G. K. et al. Autologue mononuclear stem cells and morphogenetic bone protein in experimentally induced tibial defect healing in dogs. Arquivo Brasileiro de Medicina Veterinária e Zootecnia, v. 62 , n. 1, p. 72-79, 2010. Available from: <http:// www.scielo.br/pdf/abmvz/v62n1/v62n1a10.pdf $>$. Accessed: Feb. 02, 2017. doi: 10.1590/S0102-09352010000100010.

PUOPOLO, M. Biostatistical approaches to reducing the number of animals used in biomedical research. Annales di Istituto Superiore di Sanità, v. 40, n. 2, p. 157-163, 2004. Available from: < http://old.iss. it/binary/neco/cont/Biostatistical\%20approa\%237CF9E.1147946503. pdf\#page=13\%3E $>$. Accessed: Mar. 03, 2016.

QUANDT, J. E. et al. Analgesia in critically ill patients. The Compendium on Continuing Education for practicing veterinarian Practice Veterinary-Small Animal, v. 27, n. 6, p. 433445, 2005. Available from: <http://www.vetfolio.com/anesthesia/ analgesia-in-critically-ill-patients $>$. Accessed: May 11, 2016. 
RICHTER, R.K. et al. Thoracoscopy to diagnose and to liberate adhesions in post-operative thoracotomy and in video-assisted thoracic surgery- VATS. Experimental study in dogs. Archives of Veterinary Science, v. 14, n. 2, p. 83-90, 2009. Available from: <file:///C:/Users/ quess/Downloads/TORACOSCOPIA_NO_DIAGNOSTICO_E_ NA_LIBERACAO_DE_ADER.pdf $>$. Accessed: Apr. 12, 2016. $\overline{\text { doi: }}$

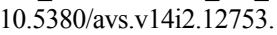

SAMPAIO, K. M. O. R. Treatment of pain in small animals. Revista do CFMV, v. 16, n. 51, p. 43-52, 2010. Available from: <https:// issuu.com/cfmvrevista/docs/cfmv51/43>. Accessed: Apr. 12, 2016.

SIA, D. B. et al. Comparation between the technique of substitution of the round ligamentum by glycerin-preserved bubaline fascia lata and the use of transarticular pin in the reduction and stabilization of experimentally induzed coxofemoral luxation in dogs. Arquivo Brasileiro de Medicina Veterinária e Zootecnia, v, v.61, n.4, p.825-834, 2009. Available from: $<$ http://www.lume.ufrgs.br/bitstream/handle/10183/77051/000713875. pdf?sequence=1>. Accessed: Apr. 07, 2016.

SILVA, E. B.; MANISCALCO, C. L. Palatoplasty with latex biomembrane with polilisine $0,1 \%$ in canine experimental palatal defect. Semina: Ciências Agrárias, v. 34, n. 2, p. 785-792, 2013. Available from: $<$ https:// repositorio.unesp.br/bitstream/handle/11449/74773/2-s2.0-84878289568. pdf? sequence=1\&isAllowed=y>. Accessed: Sept. 25, 2016. doi: 10.5433/1679-0359.2013v34n2p785.
SOUZA, T. F. B. et al. Radiographic and densitometric aspects of experimental radial fractures of dogs treated with platelet-rich plasma Ars Veterinaria, v. 27, n. 1, p. 1-6, 2011. Available from: <https:// repositorio.unesp.br/bitstream/handle/11449/133083/ISSN21750106-2011-27-01-001-006-pt.pdf? sequence $=1 \&$ is Allowed $=\mathrm{y}>$. Accessed: Apr. 29, 2016.

VALENTE, F. L. et al. Hydroxyapatite-lignin composite as a metallic implant-bone tissue osseointegration improver: experimental study in dogs. Ciência Rural, v. 46, n. 2, p. 324-329, 2016. Available from: <http://www.scielo.br/pdf/cr/v46n2/16784596-cr-0103_8478cr20150110.pdf $>$. Accessed: Feb. 02, 2017. doi: $10.1590 / 0103-8478 \mathrm{cr} 20150110$.

YAMAZAKI, M. S. et al. Analgesia e anestesia em procedimentos ortopédicos de pequenos animais. Veterinária Notícias, v. 17. n. 2, p. 77-89, 2011. Available from: <http://www.seer.ufu.br/index. php/vetnot/article/view/18979>. Accessed: Aug. 19, 2016.

YAZBEK, K. V. B.; FANTONI, D. T. Evaluation of tramadol, an "atypical" opioid analgesic in the control of immediate postoperative pain in dogs submitted to orthopedic surgical procedures. Brazilian Journal of Veterinary Research and Animal Science, v. 42, n. 4, p. 250-258, 2005. Available from: $<$ http://citeseerx.ist.psu.edu/viewdoc/download?doi=10.1.1.1031. 3111\&rep=rep1\&type=pdf. Accessed: Jun. 22, 2016. 